\title{
The Balanced Scorecard as a Basis for Strategic Company Management in the Context of the World Economy Transformation
}

\author{
Mihail Nikolaevich Dudin ${ }^{1} \&$ Evgenia Evgen'evna Frolova ${ }^{2}$ \\ ${ }^{1}$ Russian academy of Entrepreneurship, Moscow, Russian Federation \\ ${ }^{2}$ Department of the entrepreneurial and the antimonopoly law of the Far Eastern Federal University, Vladivostok, \\ Russian Federation \\ Correspondence: Mihail Nikolaevich Dudin, Russian academy of Entrepreneurship, Radio str., 14, Moscow, \\ 105005, Russian Federation. E-mail: dudinmn@mail.ru
}

Received: September 10, 2014 Accepted: October 24, 2014 Online Published: December 30, 2014

doi:10.5539/ass.v11n3p282

URL: http://dx.doi.org/10.5539/ass.v11n3p282

\begin{abstract}
The objective of this article is to develop a common methodological concept of creating the Balanced Scorecard (BSC) and the determination of a set of key performance indicators for manufacturing type companies. Authors came up with the following conclusions.

- Efficient business management under contemporary conditions becomes a complex task. Within this task, managers must not only timely identify capabilities of the external environment, but also look for internal growth reserves. When applying these reserves, manager should take into account the evolvability of the company and possible threats to the company development.

- There are many ways, methods and approaches to improve the strategic business management of contemporary companies. At that, the technique, which is based on the Balanced Scorecard, remains the most appropriate approach to build and structure company business management, as well as elaborate the long-term development strategy.

- The Balanced Scorecard is a special set of indicators that are of equal importance for analyzing and evaluating the operation and business development of companies. The Balanced Scorecard is focused on meeting the information needs of strategic planning and management.

- Created Balanced Scorecard must meet the basic requirements for managerial information, as well as show the development dynamics of all functional subsystems and business areas. Besides, the Balanced Scorecard should be adaptive and able to be updated when changing exogenous trends or shifting paradigm of managerial decisions;

- The Balanced Scorecard can be used not only in the strategic management of large companies, but can also be used by small and mid-sized companies. Small and mid-sized businesses can use a limited number of indicators, most important to make sound and rational managerial decisions.
\end{abstract}

Keywords: balanced scorecard, key performance indicators, strategic management, business process, company development

\section{Introduction}

Global changes occurring in the world economy, determine the priority of knowledge and intellectual capital as the main drivers of sustainable economic growth of contemporary businesses (Schinasi, 2014). Formation of postindustrial economic relations is a systematic evolutionary process (Sternetal, 2001), which demonstrates the intrinsic differences between the traditional and innovation-oriented business development. Physical capital of companies (tangible assets), which was significant for the traditional type of business organization and management, gives primacy to management intellectualization and innovativeness (Bose, 2007). Accordingly, new tasks on business development management rise to the fore. Among these new key objectives we make the emphases on the following:

- timely identification of emerging capabilities for business growth and possible threats to company development that correspond to these capabilities (Nickols, 2011); 
- maximizing economic value (economic value added), which creates a business, both for the company and for its stakeholders (Stewart, 1991);

- increasing and stimulating the growth of actual competitiveness due to the reorientation of business processes from the company needs to the needs of its customers (Dudin et al., 2014);

- search for financial and knowledge-based reserves for company business growth and development, focused on long-term strategic perspective (Adrianetal, 2013).

Solution of above tasks on company strategic management in today's conditions cannot be achieved using conventional managerial approaches, based on the normative planning, hard hierarchical budgeting, and deferred (reactive) response to events that had already occurred in the external environment. Traditional managerial approaches do not allow the manager to compose a full and straight pattern of the business functioning environment. This significantly impairs the development of the optimal strategy of the company development (Nedelea, 2009). In the context of post-industrialization, problems on company strategic management are usually approached through indicative planning, adaptive budgeting, as well as proactivity and anticipation of changes in external environment (Schinasi, 2014). These four aspects characterize the specifics and peculiarities of contemporary strategic business management and require the use of new tools. One of these tools, successfully tested and proven in practice, is the Balanced Scorecard (Rompho, 2006).

\section{Methodology}

This work is based on principal methodical provisions of the Balanced Scorecard. The Balance Scorecard, proposed by Robert S. Kaplan and David P. Norton in 1992 (Kaplan, 2006), takes into account four key aspects of the contemporary company operation: finance, customers, business processes, training and development. The core of the Balanced Scorecard is to formulate a financial strategy of an industrial corporation in several perspectives, setting strategic goals and measuring the degree of achievement of these goals by means of key performance indicators. One should understand that traditional accounting and controlled performance indicators of the company business (such as, in particular, the investment behavior, the statistical cost of capital, payback period, return on operating activities, etc.) do not allow management to get a clear and comprehensive pattern of the company development and factors affecting the quality and sustainability of this development.

According to R. Kaplan and D. Norton (Kaplan, 2006), the Balanced Scorecard is not so much a single one-dimensional managerial tool, allowing for the measurement of business performance, as the new management paradigm. This paradigm allows company top-management not only to develop and formalize the optimal development strategy, but also to form the basis for feedback between both the company business processes, and their performers. This, in turn, directs the entire business management system to achieve the set target strategic results.

The word "balanced» in the title means the equal importance of all indicators for the development of the company strategy. In terms of methodology, the Balanced Scorecard is a clear and formalized definition of basic criteria values, characterizing business performance efficiency (key performance indicators, KPI). At that, criteria values are itemized depending on the levels of management and business units. Also, all the tasks to be implemented by managers and employees in order to achieve desired results are specified. We can therefore conclude that the Balanced Scorecard of D. Norton and R. Kaplan is focused to a greater extent on the development of basic corporate strategies of contemporary companies. In other words, the Balanced Scorecard is the most important and powerful tool for strategic business management.

\section{Results}

The number of companies, which are using the Balanced Scorecard for strategic planning and management, developed by D. Norton and R. Kaplan, increasingly grows. Based on some data, at the beginning of the 2000's, about $44 \%$ of companies in North America used the Balanced Scorecard for strategic planning and management (Bontis, 2003). According to data of 2005, about 35\% of large and extra-large companies in Europe and Asia also began to use the Balanced Scorecard for the purpose of strategic planning and management (Effective Performance Management CIMA, 2005). Also, it is worth noting that the Balanced Scorecard is usually used by companies, whose business is characterized by high capital intensity (Effective Performance Management CIMA, 2005). This is fairly justified by the fact that significant investment volumes in company business development require not only control over the use of capital, but by the fact that investors, who invest their financial resources in the business development, are interested in the growth of their own economic benefits and economic benefits generated by the business, as well as obtaining positively evaluated social effects. That is why the strategic management of capital-intensive business is gradually moving from the traditional managerial tools, based on 
individual indicators, towards the Balanced Scorecard, and determination of key performance indicators in relation to business processes. Using the Balanced Scorecard in strategic business management allows large companies to prioritize development in the long-term perspective (Holsapple, 2004), determine the resources required, as well as to avoid unnecessary resource immobilization and to increase in general business agility and adaptability (Wheelenetal, 2006).

Although not without reason, critics of the Balanced Scorecard methodology indicate that the BSC is used less frequently in average-sized business companies, and is almost never used in small companies. This circumstance can be explained by the following reasoning.

- First, the Balanced Scorecard requires comprehensive information support, because the tool is based on a set of controlled indicators, characterizing the efficiency of various spheres of company operation and development. Small and mid-sized businesses, due to limited financial resources, cannot afford themselves to use the special information management systems that require powerful software platforms. Development of the Balanced Scorecard and monitoring of key performance indicators in the manual mode does not give the desired result;

- Secondly, not all mid-sized companies and most small companies can formulate and clearly formalize the concept of their business development strategy in the medium-term and long-term perspectives. This means that small and mid-sized businesses cannot answer the key methodological issues of the Balanced Scorecard: what position in the business space is occupied by the company at the moment, how the management characterizes company positions in the future, and what should be done to achieve the results;

- Third, on the one hand, small and mid-sized businesses have a higher ability to adapt to sudden changes of external environment compared to large and extra-large businesses. But at the same time, small-sized and mid-sized businesses have significantly less abilities to preserve the sustainability of economic growth and development in the long-term perspective.

In addition, the development of the Balanced Scorecard and the determination of the key performance indicators require modeling and formalization of business processes (Charlessetal, 2007). As a rule, in small business companies, there are two basic business processes, namely the main business process and managerial business process. In mid-sized companies, there are more core business processes, though at the same time, their modeling is complicated by the fact that some business processes are deeply integrated, because the responsibility for their implementation is assigned to an employee (or employees team), who usually combines several areas of responsibility. Therefore, at present the Balanced Scorecard and the assignment of key performance indicators to business processes is largely a tool for strategic planning and management in large (national) companies and extra-large (transnational) companies.

Small and mid-sized companies can use certain methodical aspects of the Balanced Scorecard and determine key performance indicators in planning for the long-term perspective (Addyetal, 1994). But it would be more correctly to use a limited number of factors and indicators, namely those, which reflect the key trends of business operation and development within the given competitive conditions, resource provision and undertaken business risks.

\section{Discussion}

Popularity of the Balanced Scorecard, as contemporary technique for company strategic planning and business management can be attributed to a combination of causes. In particular, the Balanced Scorecard and set key performance indicators have greater flexibility and adaptability (Abell \& Oxbrow, 2002) in regard to a changing external environmental trends and, accordingly, to changes made in regard to the company's strategic development plans. Besides, the Balanced Scorecard is applicable in large non-profit organizations, as well as in state-owned enterprises (Johnson \& Beiman, 2007), i.e. it may include not only economic indicators, but also social performance indicators of business processes. Using not only economic but also social key performance indicators allows commercial organizations to obtain comprehensive and relevant information about the specifics and trend of company socio-economic development that includes company knowledge (intellectual capital), as well as human and material resources (Niven, 2012).

It is worth noting that the Balanced Scorecard can integrate any aspects of operational management and development of the company business. In particular, for companies focused on continuous improvement of the quality of their activities and products, the Balanced Scorecard may include key performance indicators of quality management processes.

In this case, the Balanced Scorecard integrates quality management philosophy, based on the TQM (Total Quality Management) concept. The integration of quality philosophy and the Balanced Scorecard define the key 
performance indicators continuum of related business processes in strategic business management of contemporary companies. From this point, company development strategy in the long-term perspective is based on the following key methodic aspects:

- quality of products and services, rendered by the company, is determined by the customer;

- company business processes and business model are subject to continuous improvement;

- company employees become like-minded and get more powers;

- efficiency measurement of business processes within the system of set indicators allows one to provide preventive measures and the necessary changes in a timely manner.

Thus, it is obvious that the Balanced Scorecard is a powerful and effective tool for strategic management of today's business. This tool comprehensively integrates all the key aspects of the company performance, while continuously supported by feedback between management and employees.

In our opinion, the formulation of the Balanced Scorecard and the definition of key performance indicators to the specific business processes of the company should be based in practice on an integrated methodological approach (Dudin, 2014). For this purpose we suggest to structure the Balanced Scorecard through the hierarchical levels of company management (strategic, tactical and operational management levels), as well as through the business processes, associated with concerned level of control. Consequently, the formalization of the Balanced Scorecard and the determination of key performance indicators to the company business processes will be as shown in Figure 1.

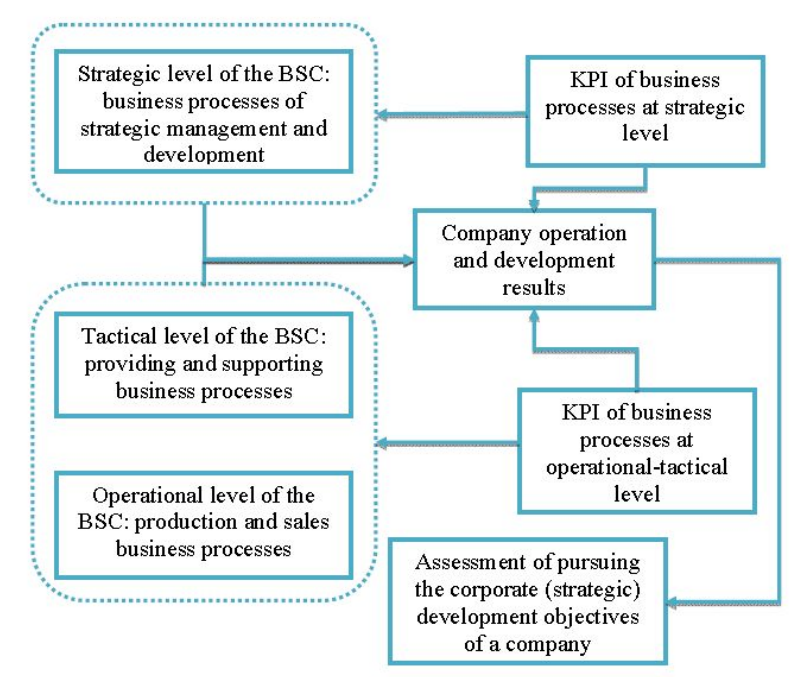

Figure 1. An integrated approach to formalization of the Balanced Scorecard and determination of key performance indicators

The Balanced Scorecard with defined key performance indicators of company business processes, in our opinion, must meet the following basic requirements:

1. Scorecard (as well as key performance indicators) reflect the characteristics of strategic and functional efficiency of the company operation and development;

2. Scorecard (as well as key performance indicators) show the status and development dynamics (changes) of all (major) subsystems of company management;

3. Scorecard (as well as key performance indicators) is able to be upgraded when changing the managerial requirements or transforming the company operation and development specificity.

Thus, the Balanced Scorecard incorporates all levels of business management and all business processes. At that, the key performance indicators are assigned to each business process. Comparison of actual progress in the operation and development of a company during a certain period or number of previous periods with defined key performance indicators allows us to assess the achievement of the objectives of corporate development and, at the same time, to identify the problems in company activities, which will be clearly specified and localized in terms of each business process. 
Concrete definition of key performance indicators, assigned to specific business processes, is the greatest difficulty for companies. It should be clearly understood that each indicator should be intrinsic and relevant to characterize the efficiency and effectiveness of the business process. This is a major and necessary condition for strategic business management based on the Balanced Scorecard tool.

In practice, very often companies assign key performance indicators based only on the basic classification of business processes. Recall that the basic classification of business processes involves the arrangement of all business processes in three main groups:

1) management-related and development-related business processes, which are focused on the future and do not generate direct economic benefits of the company in the current and the short-term perspectives, but potentiate the growth of economic (and other) benefits of the company (as well as the company investors) in long-term strategic perspective;

2) the core business processes, which are focused on the generation of current economic and other benefits of the company (and its investors), as well as on the formation of reserves to ensure sustainable growth and development of business in the long-term perspective;

3) provision-related and support-related business processes, which do not generate direct economic benefits in the short-term or long-term perspectives, but are intended to support and resourcing both key business processes and development and management business processes. Providing and supporting business processes generate indirect economic benefits of a company.

Lack of specification and circumstantiation of business processes belonging to a particular company in each group of business processes, does not allow one to determine the nature and purpose of these processes. Besides, the lack of a clear structuring and systematization of business processes, which are implemented by the company, is the main managerial problem, when implementing the Balanced Scorecard into the strategic management. In other words, if the company management does not have a common vision of business processes organizing and structuring, it will be very difficult for company to ensure the implementation of the corporate development strategy and to target company on achieving the desired strategic outcome.

Based on the experience of companies that have successfully implemented the Balanced Scorecard, as well as taking into account scientific and empirical studies, conducted by the authors earlier, and the studies, carried out by other scientists, we believe that industrial companies could adopt the following systematization and structuring of business processes and related effectiveness indicators and indices (Table 1).

Table 1. The Balanced Scorecard of industrial companies.

\begin{tabular}{|c|c|}
\hline & \\
\hline $\begin{array}{l}\text { ss processes related to strategic management } \\
\text { elopment. }\end{array}$ & $\begin{array}{l}\text { siness processes related to production and } \\
\text { eration. KPI: }\end{array}$ \\
\hline & \\
\hline perfor & $\begin{array}{l}\text { ility of production and sales; } \\
\text { eting and operating activities. }\end{array}$ \\
\hline $\begin{array}{l}\text { dded: reflects the company's } \\
\text { itional profits for shareholders }\end{array}$ & \\
\hline & $\begin{array}{l}\text { cial responsibility; } \\
\text { of operational and }\end{array}$ \\
\hline $\begin{array}{l}\text { act the } \mathrm{nc} \\
\text { and } \mathrm{cc}\end{array}$ & $\begin{array}{l}\text { iness processes. KPI: } \\
\text { provision by necessary human } \\
\text { on staff categories); } \\
\text { n the dynamics of investment } \\
\text { development and the value of } \\
\text { capital; } \\
\text { ent in personnel development (in }\end{array}$ \\
\hline
\end{tabular}


The Balanced Scorecard, presented in Table 1, includes two components, consisting of business processes and assigned key performance indicators. Business processes of company strategic management are generally directed to the external environment and determine the level of sustainable and competitive development of the company. Production, operational, personnel and financial business processes are directed to the internal environment of the company. Accordingly, key performance indicators, focused on the external environment, reflect the strategic effectiveness of company operation and development. In turn, the key performance indicators, focused on the internal environment, reflect the functional and operational efficiency of company operation and development. In summary, note that the above proposed approach to building the Balanced Scorecard and determining key performance indicators of business processes aggregates and monitors all relevant factors and events that occur in both the internal and the external environment, as well as determine the trajectory of the company business in the current and long term perspective.

\section{Conclusion}

The research conducted shows that the Balanced Scorecard is one of the most effective methodic concepts of strategic business management of contemporary companies. The Balanced Scorecard is primarily focused on providing the information needs of strategic management in large and extra-large companies (of national and transnational scale). However, small and mid-sized businesses can also use methodological solutions proposed in this paper, though in condensed version. For example, small and mid-sized companies can assess their abilities to create economic value added, sustainability of economic growth, as well as certain, the most important, results in the production-, operation-, finance- or personnel-related business processes. The Balanced Scorecard, proposed in this paper, is targeted on providing information needs of strategic management in industrial-type companies. The latest is its main constraint. But it is worth noting that the proposed Balanced Scorecard tool is quite adaptable and has universal nature. It can be tailored based on the managerial information needs of retail, service and financial companies.

\section{References}

Abell, A., \& Oxbrow, N. (2002). Competing with knowledge. London: Library Association Publishing.

Addy, C., Pearce, J., \& Bennett, J. (1994). Performance measures in small manufacturing enterprises: Are firms measuring what matters? In Proceeding of the 10th National Conference on Manufacturing Research. Loughborough, UK.

Adrian, T., Covitz, D., \& Liang, N. (2013). Financial Stability Monitoring. Finance and Economics Discussion Series Divisions of Research \& Statistics and Monetary Affairs/ Federal Reserve Board. Washington, D.C.

Bontis, N. (2003). Intellectual capital disclosure in Canadian corporations. Journal of Human Resource Costing and Accounting, 7(1/2), 9-20. http://dx.doi.org/10.1108/eb029076

Bose, S. (2007). Applying the balanced scorecard for better performance of intellectual capital. Journal of Intellectual Capital, 8(4), 653-665. http://dx.doi.org/10.1108/14691930710830819

Charless, W., Hill, L., \& Gareth, R. (2007). Strategic Management Theory: An Integrated Approach. Biztantra: Wiley India.

CIMA. (2005). Effective Performance Management with the Balanced Scorecard. Technical Report.

Dudin, M. N. (2014). Innovative Development Path as a Form of Business Enterprises' Activity Boost. European Researcher, 74(5-1), 831-836.

Dudin, M. N., Lyasnikov, N. V., Yahyaev, M. A., \& Kuznetzov, A. V. (2014). The organization approaches peculiarities of an industrial enterprises financial management. Life Science Journal, 11(9), 333-336.

Holsapple, C. (2004). Handbook on Knowledge Management: Knowledge Directions, 2, Springer. http://dx.doi.org/10.1007/978-3-540-24746-3

Johnson, C., \& Beiman, I. (2007). Balanced Scorecard for State-Owned Enterprises Driving Performance and Corporate Governance. Asian Development Bank.

Kaplan, R., \& Norton, D. (2006). Alignment: Using the Balanced Scorecard to Create Corporate Synergies. Harvard: Harvard Business School Press.

Nedelea, S., \& Paun, L. (2009). The Importance of the Strategic Management Process in the Knowledge-Based Economy. Review of International Comparative Management, 10(1), 95-105.

Nickols, F. (2011). Strategy, strategic management, strategic planning and strategic thinking. Distance Consulting LLC. 
Niven, P. (2012). Balanced Scorecard step-by-step: maximizing performance and maintaining results. New York, John Wiley \& Sons.

Rompho, N. (2011). Why the Balanced Scorecard Fails in SMEs: A Case Study. International Journal of Business and Management, 6(11). http://dx.doi.org/10.5539/ijbm.v6n11p39

Schinasi, G. (2004). Defining Financial Stability. International Monetary Fund (WP/14/187).

Stern, J., Shiely, J., \& Ross, I. (2001). The EVA challenge: implementing value-added change in an organization. John Wiley \& Sons, Inc.

Stewart, G. (1991). The Quest for Value. NY: Harper Business.

Wheelen, T., Hunger, J., \& Rangarajan, K. (2006). Strategic Management and Business policy. Pearson Education.

\section{Copyrights}

Copyright for this article is retained by the author(s), with first publication rights granted to the journal.

This is an open-access article distributed under the terms and conditions of the Creative Commons Attribution license (http://creativecommons.org/licenses/by/3.0/). 